\title{
Cronobacter condimenti sp. nov., isolated from spiced meat, and Cronobacter universalis sp. nov., a species designation for Cronobacter sp. genomospecies 1, recovered from a leg infection, water and food ingredients
}

\author{
Susan Joseph, ${ }^{1}$ Esin Cetinkaya, ${ }^{2}$ Hana Drahovska, ${ }^{3}$ Arturo Levican, ${ }^{4}$ \\ Maria J. Figueras ${ }^{4}$ and Stephen J. Forsythe ${ }^{1}$ \\ ${ }^{1}$ School of Science and Technology, Nottingham Trent University, Clifton Lane, \\ Nottingham NG11 8NS, UK \\ ${ }^{2}$ Food Engineering Department, Engineering Faculty, Ankara University, Ankara, Turkey \\ ${ }^{3}$ Department of Molecular Biology, Faculty of Natural Sciences, Comenius University, Bratislava, \\ Slovakia \\ ${ }^{4}$ Unit of Microbiology, Rovirai Virgili University, IISPV, Sant Llorenç, 43201 Reus, Spain
}

\begin{abstract}
A re-evaluation of the taxonomic position of five strains, one assigned to Cronobacter sakazakii (strain $1330^{\top}$, isolated from spiced meat purchased in Slovakia), two previously assigned to Cronobacter genomospecies 1 (strains NCTC $9529^{\top}$ and 731, isolated from water and a leg infection, respectively) and two previously assigned to Cronobacter turicensis (strains 96 and 1435 , isolated from onion powder and rye flour, respectively) was carried out. The analysis included phenotypic characterization, 16S rRNA gene sequencing and multilocus sequence analysis (MLSA) of seven housekeeping genes ( $a t p D, f u s A, g \ln S, g l t B, g y r B$, infB, ppsA; $3036 \mathrm{bp}$ ). $16 \mathrm{~S}$ rRNA gene sequence analysis and MLSA showed that strain $1330^{\top}$ formed an independent phylogenetic lineage in the MLSA, with Cronobacter dublinensis LMG $23823^{\top}$ as the closest neighbour. DNA-DNA reassociation and phenotypic analysis revealed that strain $1330^{\top}$ represented a novel species, for which the name Cronobacter condimenti sp. nov. is proposed (type strain $1330^{\top}=$ CECT $7863^{\top}=$ LMG $26250^{\top}$ ). Strains NCTC $9529^{\top}, 731,96$ and 1435 clustered together within an independent phylogenetic lineage, with C. turicensis LMG $23827^{\top}$ as the closest neighbour in the MLSA. DNA-DNA reassociation and phenotypic analysis confirmed that these strains represent a novel species, for which the name Cronobacter universalis sp. nov. is proposed (type strain NCTC $9529^{\top}=$ CECT $7864^{\top}=$ LMG $26249^{\top}$ ).
\end{abstract}

The genus Cronobacter was created by the reclassification of the species Enterobacter sakazakii (Iversen et al., 2007) and belongs to the family Enterobacteriaceae of the class Gammaproteobacteria. It includes facultatively anaerobic,

\footnotetext{
Abbreviations: MLSA, multilocus sequence analysis; MLST, multilocus sequence typing.

The GenBank/EMBL/DDBJ accession numbers for the 16S rRNA gene sequences of strains $1330^{\top}$, NCTC $9529^{\top}, 1435,731$ and 96 are FN539031, EF059877 and JN205049-JN205051, respectively, and for the $\operatorname{atp} D$, fus $A, g / n S, g l t B, g y r B$, infB and $p p s A$ sequences of $C$. sakazakii ATCC $29544^{\top}$, C. malonaticus LMG $23826^{\top}$, C. muytjensii ATCC $51329^{\top}$, C. dublinensis LMG $23823^{\top}$, C. turicensis LMG $23827^{\top}$, strain NCTC $9529^{\top}$, strain $1330^{\top}$ and Citrobacter koseri ATCC BAA-895 are JF268258-JF268313; they can also be accessed from the Cronobacter multilocus sequence typing website (http://pubmlst.org/ cronobacter).
}

Gram-negative, oxidase-negative, catalase-positive, nonspore-forming rods that, in general, are motile, able to reduce nitrate to nitrite and to produce acetoin (VogesProskauer test), and negative for the methyl red test (Iversen et al., 2007). Species of this genus are primarily inhabitants of plant material and are often associated with human diseases, most notably severe neonatal infections (Iversen \& Forsythe, 2004; Forsythe, 2005; Osaili \& Forsythe, 2009). The genus includes five species, which were differentiated according to the 16 E. sakazakii biogroups, each biogroup being defined by their phenotype based on 10 tests (Farmer et al., 1980; Iversen et al., 2006b): Cronobacter sakazakii (biogroups 1-4, 7, 8, 11 and 13), Cronobacter malonaticus (biogroups 5, 9 and 14), Cronobacter turicensis (biogroups 16, 16a and 16b), Cronobacter muytjensii (biogroup 15) and Cronobacter dublinensis (biogroups 6, 
10 and 12) (Iversen et al., 2007, 2008). However, not all E. sakazakii strains were accommodated in the genus Cronobacter. Strain NCTC $9529^{\mathrm{T}}$, the sole member of biogroup $16 c$, was suspected to represent another species of the genus Cronobacter, but insufficient strains and biochemical tests were available to define the species and consequently strain NCTC $9529^{\mathrm{T}}$ was assigned to Cronobacter genomospecies 1 (Iversen et al., 2007).

The taxonomy of the genus Cronobacter is complex due to the high interspecies similarity of the 16S rRNA gene sequences, which ranges from 97.8 to $99.7 \%$, the overlap of biochemical profiles and a poor correlation between genotypic and phenotypic analyses (Duaga \& Breuwer, 2008; Kucerova et al., 2010). Furthermore, confusions with other members of the Enterobacteriaceae have been described: a number of Enterobacter cloacae and Enterobacter hormaechei strains isolated from human infections were assigned to the genus Cronobacter using phenotypic tests (CaubillaBarron et al., 2007; Townsend et al., 2008). The existence of microheterogeneities in the 16S rRNA gene sequence is another factor that can generate misidentifications, as has been reported for certain strains of $C$. sakazakii and $C$. malonaticus that could not be differentiated (Iversen et al., 2007). Multilocus sequence analysis (MLSA) based on the sequences of housekeeping genes has proven to be a useful tool for the Enterobacteriaceae (Lacher et al., 2007; Ibarz Pavón \& Maiden, 2009). Baldwin et al. (2009) applied MLSA based on seven housekeeping genes (atpD, fusA, $g \ln S, g l t B, g y r B$, infB and $p p s A$ ) to $C$. sakazakii and $C$. malonaticus and demonstrated a robust phylogenetic analysis that separated the two species. The latter study also showed that some previous confusion between the two species may have been due to incorrect species identification of some biotype index strains (Baldwin et al., 2009). Further MLSA revealed a clear differentiation of all members of the genus Cronobacter and the association of C. sakazakii sequence type 4 with neonatal meningitis (Joseph \& Forsythe, 2011; Kucerova et al., 2011). The scheme has open access at the Cronobacter multilocus sequence typing (MLST) website (http://pubmlst.org/ cronobacter). The present investigation determined the taxonomic position of five Cronobacter strains recovered from a leg infection, spiced meat, water and two food ingredients (onion powder and rye flour).

Strain $1330^{\mathrm{T}}$ (also known as strain $040407 / 32^{\mathrm{T}}$ ) was previously isolated from spiced meat purchased in Slovakia (Turcovský et al., 2011). Phenotypic analysis placed it in biogroup 1 and therefore as a strain of C. sakazakii (Iversen et al., 2007). However, partial 16S rRNA gene sequence analysis (657 bp) showed the nearest match was C. dublinensis (Turcovský et al., 2011). Strain $1330^{\mathrm{T}}$ was isolated at $45{ }^{\circ} \mathrm{C}$ using selective enrichment in a modified lauryl sulfate tryptose broth containing $0.5 \mathrm{~mol} \mathrm{NaCl} 1^{-1}$ and $10 \mathrm{mg}$ vancomycin $\mathrm{l}^{-1}$ and then plating onto Cronobacter chromogenic agar and selecting colonies, as described by Turcovský et al. (2011). Using an API 20 E kit (bioMérieux) and additional recommended tests (Farmer et al., 1980; Iversen et al., 2006b), strain $1330^{\mathrm{T}}$ was phenotypically verified as a member of the genus Cronobacter and biogroup 1.

NCTC $9529^{\mathrm{T}}$ was previously assigned to E. sakazakii biogroup $16 \mathrm{c}$ as defined by Iversen et al. (2006b) on the basis of non-motility, acid production from inositol and dulcitol and utilization of malonate. The strain was later assigned to Cronobacter genomospecies 1 (Iversen et al., 2007). The remaining strains within biogroup 16 were defined as C. turicensis based on phenotyping, DNA-DNA hybridization and amplified fragment length polymorphism (Iversen et al., 2007).

Strain 731 was isolated in 2005 from a post-operative mixed infection of a 9-year-old boy with humeral fracture treated by osteosynthesis using intra-medullar nailing. The strain was phenotypically identified as E. sakazakii and not further characterized. Staphylococcus aureus was also isolated from the infected site (M.-F. Prère, personal communication).

Strain 96 was isolated from onion powder purchased in the UK using Enterobacteriaceae enrichment broth and E. sakazakii chromogenic agar, as described by Iversen \& Forsythe (2004). The strain was phenotypically identified as a member of E. sakazakii and assigned to biogroup 16 on the basis of motility, acid production from inositol and dulcitol, and utilization of malonate and ornithine (Iversen et al., 2006b). It was assigned to E. sakazakii cluster 2 according to its partial $16 \mathrm{~S}$ rRNA gene sequence (528 bp) (accession no. AY579172) and hsp60 sequence (accession no. AY579197) by Iversen et al. (2004). Cluster 2 was later renamed without further analysis of strain 96 as $C$. turicensis in the taxonomic revision of E. sakazakii (Iversen et al., 2007).

Strain 1435 was isolated from rye flour purchased in Turkey using Enterobacteriaceae enrichment broth and Cronobacter chromogenic agar. The strain was phenotypically identified as a member of the genus Cronobacter in our laboratory.

The phenotypic tests used to evaluate strains $1330^{\mathrm{T}}$, NCTC $9529^{\mathrm{T}}, 731,96$ and 1435 in the present study were selected from Iversen et al. (2006a, b, 2007, 2008): catalase and oxidase activity, nitrate reduction, acid production from sugars, malonate utilization, production of indole from tryptophan, motility, gas from D-glucose, Voges-Proskauer, methyl red, $\alpha$-glucosidase activity, pigment production on tryptone soy agar (TSA; 21 and $37^{\circ} \mathrm{C}$ ), aerobic and anaerobic growth on TSA $\left(37^{\circ} \mathrm{C}\right)$, growth on MacConkey agar and hydrolysis of DNA. Acid production from carbohydrates was determined in nutrient broth supplemented with phenol red and the following substrates (1\%, w/v): sucrose, L-arabinose, cellobiose, lactose, raffinose, Lrhamnose, inositol, D-mannitol, D-sorbitol, $\mathrm{N}$-acetylglucosamine and salicin. These tests were performed at least twice using conventional methods and, additionally, some tests (production of indole and hydrogen sulphide, VogesProskauer test, $\alpha$-glucosidase and $\beta$-galactosidase, ornithine 
decarboxylase, hydrolysis of gelatin and urea and acid production from D-mannitol, D-sorbitol, L-rhamnose, myoinositol, sucrose and L-arabinose) were performed in parallel using the API $20 \mathrm{E}$ and ID $32 \mathrm{E}$ systems (bioMérieux). Fermentation/oxidation of 49 carbohydrates was tested using the API $50 \mathrm{CH}$ system (bioMérieux), according to the manufacturer's instructions. Appropriate positive and negative controls were included. All tests were performed at $37^{\circ} \mathrm{C}$ and evaluated for $48 \mathrm{~h}$. Type strains belonging to all species of the genus Cronobacter were evaluated under identical conditions for the selected differential tests included in Table 1. Between three and 12 of these tests were able to distinguish the test strains from other members of the genus Cronobacter.

Strains $1330^{\mathrm{T}}$, NCTC $9529^{\mathrm{T}}, 731,96$ and 1435 were Gramnegative, oxidase-negative, catalase-positive, facultatively anaerobic rods that were positive for acetoin production (Voges-Proskauer) and yellow pigmentation on TSA at $21{ }^{\circ} \mathrm{C}$ after $48 \mathrm{~h}$ and negative for the methyl red test. They fermented glucose, sucrose, cellobiose, arabinose, mannitol, amygdalin and galacturonic acid, reduced nitrate, utilized citrate, malonate and ornithine, and exhibited delayed DNase activity. They did not hydrolyse urea or produce acid from sorbitol, 5-ketogluconate or adonitol. These traits are common in the genus Cronobacter (Iversen et al., 2007, 2008).

Strain $1330^{\mathrm{T}}$ was found to be biochemically different from all other members of the genus Cronobacter by at least six different characters (Table 1). This strain was classified as a member of C. sakazakii (biogroup 1) using criteria of Farmer et al. (1980), but on the basis of the present results it could be differentiated from this biogroup because it was not motile, was able to produce indole from tryptophan and to utilize malonate, and was not able to produce acid from turanose, inositol, lactulose, putrescine, cis-aconitate, 4-aminobutyrate, maltitol or palatinose. Strain $1330^{\mathrm{T}}$ was relatively similar to strains NCTC $9529^{\mathrm{T}}, 731,96$ and 1435 but could be differentiated from them by several characters, i.e. indole production and no acid production from dulcitol, melezitose, inositol, lactulose and maltitol (Table 1).

Strains NCTC $9529^{\mathrm{T}}, 731,96$, and 1435 were found to be biochemically similar and different from all other members of the genus Cronobacter by at least three characters (Table 1). They could be differentiated from C. turicensis (biogroups $16,16 \mathrm{a}$ and 16b) because they did not produce acid from turanose, putrescine or 4-aminobutyrate.

The susceptibility of strains $1330^{\mathrm{T}}$, NCTC $9529^{\mathrm{T}}, 731,96$ and 1435 to 17 antibiotics was assessed according to the standards and procedures of the British Society for Antimicrobial Chemotherapy (2010). The strains were classified as susceptible, intermediate or resistant. Discs (Mast Diagnostics) containing the following antibiotics were used ( $\mu$ g per disc): amikacin (30), ampicillin (10), amoxicillin/ clavulanic acid (30), cefotaxime (30), cefuroxime (30), cefpodoxime (10), ceftazidime (30), chloramphenicol (30), ciprofloxacin (1), doxycycline (30), gentamicin (10), imipenem (10), piperacillin/tazobactam (75/10), trimethoprim (2.5), ceftazidime/clavulanic acid (30/10), cefotaxime/ clavulanic acid (30/10) and cefpodoxime/clavulanic acid $(10 / 1)$ were tested.

Table 1. Phenotypic characters differentiating Cronobacter condimenti sp. nov., Cronobacter universalis sp. nov. and other members of the genus Cronobacter

Taxa: 1, Cronobacter condimenti sp. nov. $1330^{\mathrm{T}} ; 2$, Cronobacter universalis sp. nov. (n=4); 3, C. sakazakii ATCC 29544 ${ }^{\mathrm{T}}$; 4, C. malonaticus LMG $23826^{\mathrm{T}}$; 5, C. turicensis LMG $23827^{\mathrm{T}}$; 6, C. muytjensii ATCC $51329^{\mathrm{T}}$; 7, C. dublinensis subsp. dublinensis LMG $23823^{\mathrm{T}}$; 8 , C. dublinensis subsp. lactaridi; 9, C. dublinensis subsp. lausannensis. Data in columns 1 and 2 and in parentheses (i.e. results for type strains) were obtained in this study and data in columns 3-9 were from Iversen et al. (2007, 2008). +, Positive; v, 20-80\% variable; -, negative.

\begin{tabular}{|c|c|c|c|c|c|c|c|c|c|}
\hline Characteristic & 1 & 2 & 3 & 4 & 5 & 6 & 7 & 8 & 9 \\
\hline \multicolumn{10}{|l|}{ Carbon utilization: } \\
\hline Indole & + & $-(-)$ & $-(-)$ & $-(-)$ & $-(-)$ & $+(+)$ & $+(+)$ & + & $\mathrm{v}$ \\
\hline Malonate & + & $+(+)$ & $-(-)$ & $+(+)$ & $\mathrm{v}(+)$ & $+(+)$ & $+(+)$ & - & - \\
\hline 10-Methyl $\alpha$-D-glucopyranoside & + & $+(+)$ & $+(+)$ & $+(+)$ & $+(+)$ & $-(-)$ & $+(+)$ & + & + \\
\hline Turanose & - & $-(-)$ & $+(+)$ & $+(+)$ & $+(+)$ & $\mathrm{v}(+)$ & $+(+)$ & $\mathrm{V}$ & - \\
\hline Inositol & - & $+(+)$ & $\mathrm{v}(+)$ & $\mathrm{v}(-)$ & $+(+)$ & $+(+)$ & $+(+)$ & + & - \\
\hline Lactulose & - & $+(+)$ & $+(+)$ & $+(+)$ & $+(+)$ & $+(+)$ & $+(+)$ & + & - \\
\hline Putrescine & - & $-(-)$ & $+(+)$ & $\mathrm{v}(+)$ & $+(+)$ & $+(+)$ & $+(+)$ & + & $\mathrm{v}$ \\
\hline cis-Aconitate & - & $\mathrm{V}(-)$ & $+(+)$ & $+(+)$ & $+(+)$ & $+(+)$ & $+(+)$ & + & + \\
\hline trans-Aconitate & - & $-(-)$ & $-(-)$ & $+(+)$ & $-(-)$ & $+(+)$ & $+(+)$ & + & + \\
\hline
\end{tabular}




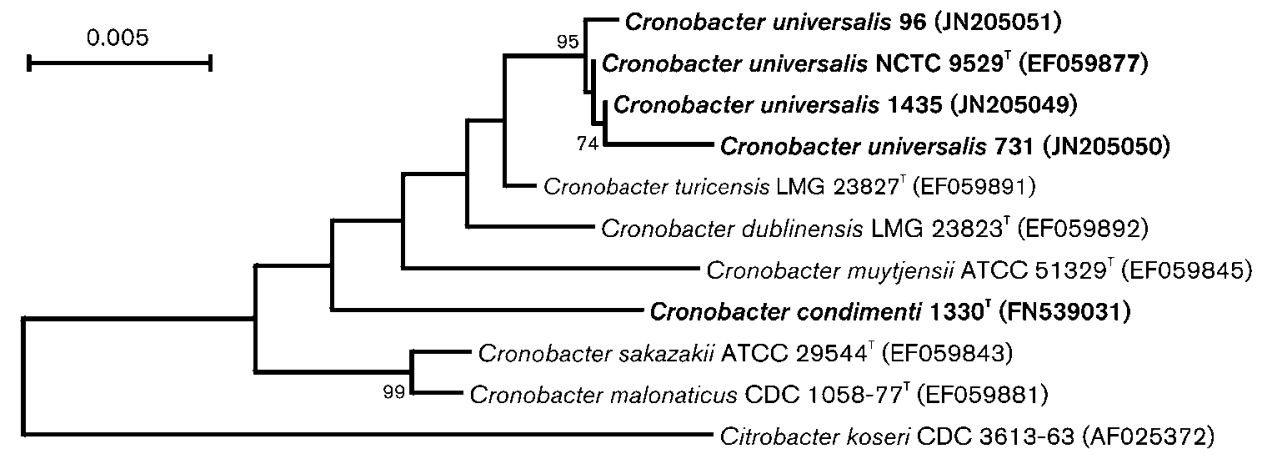

Fig. 1. Neighbour-joining phylogenetic tree derived from $16 \mathrm{~S}$ rRNA gene sequences (1361 bp), showing positions of strains $1330^{\top}$, NCTC $9529^{\top}, 96,731$ and 1435 in the genus Cronobacter. Bootstrap values $(>70 \%)$ based on 1000 replications are shown at branch nodes. Bar, 5 substitutions per 1000 nucleotide positions.

For phylogenetic studies of the 16S rRNA gene and seven housekeeping genes (MLSA), strains were cultured on TSA at $37{ }^{\circ} \mathrm{C}$. DNA was extracted from a single colony by using a GenElute Bacterial Genomic DNA kit (Sigma-Aldrich), according to the manufacturer's instructions. The primers and conditions for amplification and sequencing of the $16 \mathrm{~S}$ rRNA gene (1361 bp), atpD (390 bp), fusA (438 bp), glnS (363 bp), gltB (507 bp), gyrB (402 bp), infB (441 bp) and ppsA (495 bp) genes have been described elsewhere (Iversen et al., 2007; Baldwin et al., 2009). Amplification products were sequenced with an ABI sequencer (Applied Biosystems). 16S rRNA gene sequences (1361 bp) for the type strains of all members of the genus Cronobacter were obtained from GenBank and available housekeeping gene sequences (Baldwin et al., 2009) were obtained from the MLST database. Sequences were independently aligned using CLUSTAL W version 2 (Larkin et al., 2007) and MEGA version 4 (Tamura et al., 2007). Genetic distances and clustering were determined using Kimura's two-parameter model (Kimura, 1980) and evolutionary trees were reconstructed using the neighbour-joining method (Saitou \& Nei, 1987). The stability of the relationships was assessed using the bootstrap method with 1000 replicates. The 16S rRNA gene sequence similarities (1361 bp) were determined using the EzTaxon server (Chun et al., 2007).

The 16S rRNA gene phylogenetic tree of the genus Cronobacter (Fig. 1.) showed that strain $1330^{\mathrm{T}}$ formed one independent lineage and that strains NCTC $9529^{\mathrm{T}}, 731,96$ and $1435^{\mathrm{T}}$ formed another independent lineage within the cluster containing C. dublinensis $\mathrm{DES} 187^{\mathrm{T}}$ and C. turicensis $\mathrm{z} 3032^{\mathrm{T}}$. 16S rRNA gene sequence similarities between strains $1330^{\mathrm{T}}$ and NCTC $9529^{\mathrm{T}}$ and the other recognized members of the genus Cronobacter were 99.7-98.2\%, which corresponds to $4-24 \mathrm{bp}$ difference. The highest sequence similarities were obtained between strain NCTC $9529^{\mathrm{T}}$ and C. turicensis $\mathrm{z}_{3032^{\mathrm{T}}}$ (99.7\%; 4 bp difference) and between strain $1330^{\mathrm{T}}$ and C. turicensis $\mathrm{z} 3032^{\mathrm{T}}$ (98.6\%; 19 bp difference). Sequence similarities between strain NCTC $9529^{\mathrm{T}}$ and strains 731, 96 and 1435 were 99.4, 99.6 and $99.7 \%(8,5$ and $4 \mathrm{bp}$ difference), respectively.

MLSA showed that strains $1330^{\mathrm{T}}$, NCTC $9529^{\mathrm{T}}, 731,96$ and 1435 belonged to the genus Cronobacter, but represented two independent branches (Fig. 2). The MLSA phylogenetic tree revealed that the closest phylogenetic neighbour to strain $1330^{\mathrm{T}}$ was C. dublinensis LMG $23823^{\mathrm{T}}$, despite strain $1330^{\mathrm{T}}$ having highest 16S rRNA gene sequence similarity with C. turicensis $\mathrm{z} 3032^{\mathrm{T}}$. However, $C$. turicensis LMG $23827^{\mathrm{T}}$ was the closest neighbour of strains NCTC $9529^{\mathrm{T}}, 731,96$ and 1435 , as also shown by $16 \mathrm{~S}$ rRNA gene sequence analysis.

DNA-DNA hybridization (direct and reciprocal) experiments were performed between strains $1330^{\mathrm{T}}$ and NCTC $9529^{\mathrm{T}}$ and between these two strains and the type strains of the currently accepted species of the genus Cronobacter. DNA was extracted according to Marmur (1961) and DNADNA hybridization was conducted according to Urdiain et al. (2008) under optimal conditions at $68{ }^{\circ} \mathrm{C}$. Single- and double-stranded DNA was separated with hydroxyapatite. Colour development was measured at $405 \mathrm{~nm}$ using a Bio Whittaker Kinetic-QCL microplate reader. DNA-DNA reassociation values were determined at least three times. All results were below the $70 \%$ limit for species definition (Table 2) (Wayne et al., 1987; Stackebrandt \& Goebel, 1994). Although DNA-DNA relatedness is considered to give information on the similarity of entire bacterial genomes, it has been criticized because of the high number of experimental errors, the lack of reproducibility and the failure to generate collective databases (Rosselló-Mora, 2006). Moreover, DNA-DNA relatedness does not provide any information concerning phylogenetic relationships (Harayama \& Kasai, 2006), in contrast to the phylogenetic reconstruction with MLSA (Baldwin et al., 2009).

16S rRNA gene sequencing, MLSA, DNA-DNA relatedness and phenotypic characterization clearly differentiated strains $1330^{\mathrm{T}}$, NCTC $9529^{\mathrm{T}}, 731,96$ and 1435 from existing species of the genus Cronobacter and showed that they constituted 


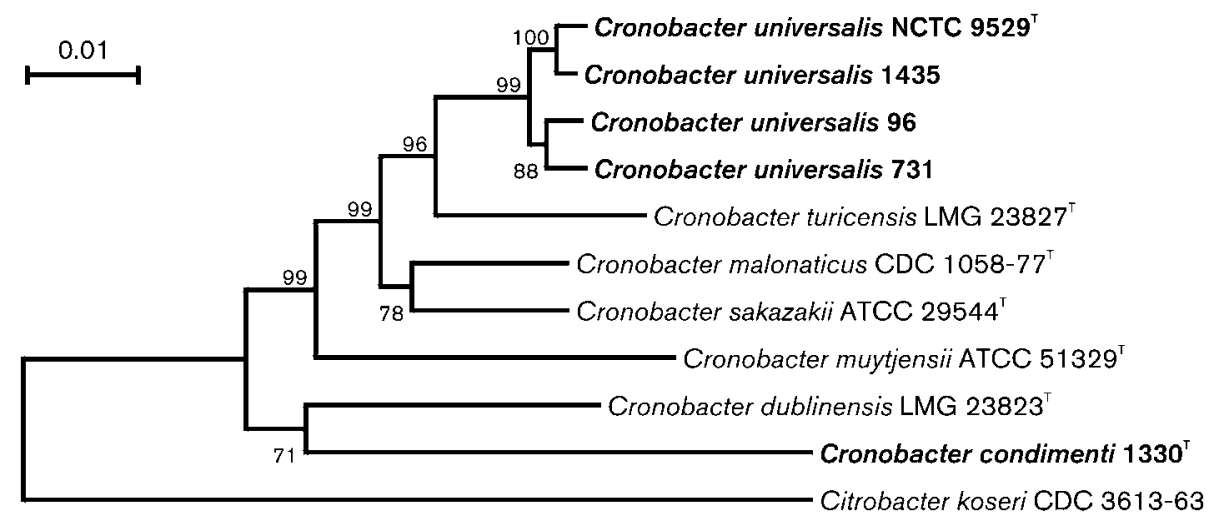

Fig. 2. Neighbour-joining phylogenetic tree based on concatenated atp $D, f u s A, g \ln S, g / t B$, gyr $B$, infB and pps $A$ sequences

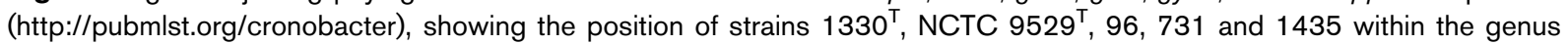
Cronobacter. Bootstrap values $(>70 \%)$ based on 1000 replications are shown at branch nodes. Bar, 1 substitution per 100 nucleotide positions.

two independent lineages within the genus. Therefore, two novel species are proposed to accommodate these strains: Cronobacter condimenti sp. nov. (strain $1330^{\mathrm{T}}$ ) and Cronobacter universalis sp. nov. (strains NCTC 9529 ${ }^{\mathrm{T}}, 731,96$ and 1435).

\section{Description of Cronobacter condimenti sp. nov.}

Cronobacter condimenti (con.di.men'ti. L. gen. n. condimenti of spice, seasoning).

Cells are straight, Gram-negative, non-motile, non-sporeforming rods. Colonies on TSA incubated at $37{ }^{\circ} \mathrm{C}$ for $24 \mathrm{~h}$ are $2-3 \mathrm{~mm}$ in diameter, opaque, circular and yellow. Grows on MacConkey agar. In TSB, grows at $45{ }^{\circ} \mathrm{C}$ (optimum $37{ }^{\circ} \mathrm{C}$ ), but not at $5{ }^{\circ} \mathrm{C}$. No haemolysis is observed on sheep blood agar at $37{ }^{\circ} \mathrm{C}$. Produces catalase, $\alpha$-glucosidase, $\beta$ galactosidase and DNase, but not oxidase. Produces acetoin (Voges-Proskauer positive) and indole from tryptophan, but not hydrogen sulphide. Hydrolyses gelatin, but not urea. Reduces nitrate. Does not produce gas from glucose. Utilizes ornithine, citrate and malonate. Produces acid from 10methyl $\alpha$-D-glucopyranoside, glycerol, L-arabinose, ribose,
D-xylose, galactose, D-glucose, D-fructose, D-mannose, Lrhamnose, D-mannitol, $N$-acetylglucosamine, arbutin, aesculin, salicin, cellobiose, maltose, lactose, melibiose, sucrose, trehalose, myo-inositol, raffinose, $\beta$-gentiobiose, D-fucose, $\mathrm{L}-$ fucose and galacturonic acid, but not from dulcitol, inositol, melezitose, turanose, lactulose, putrescine, cis- or transaconitate, 4-aminobutyrate, maltitol, palatinose, D-erythritol, D-arabinose, adonitol, methyl $\beta$-D-xyloside, L-sorbose, dulcitol, sorbitol, methyl $\alpha$-D-glucoside, inulin, glycogen, xylitol, D-lyxose, D-tagatose, D-arabitol, L-arabitol, gluconate, 2-ketogluconate or 5-ketogluconate. Resistant to doxycycline; susceptible to the other antimicrobials tested. The API $20 \mathrm{E}$ and ID $32 \mathrm{E}$ profiles of the type strain are 3367373 and 342137610030 , respectively.

The type strain is $1330^{\mathrm{T}}\left(=\mathrm{CECT} 7863^{\mathrm{T}}=\mathrm{LMG} 26250^{\mathrm{T}}\right)$, isolated from spiced meat purchased in Slovakia.

\section{Description of Cronobacter universalis sp. nov.}

Cronobacter universalis (u.ni.ver.sa'lis. L. masc. adj. universalis of or belonging to all, universal).

Table 2. DNA-DNA relatedness between Cronobacter condimenti sp. nov. and Cronobacter universalis sp. nov. with other members of the genus Cronobacter

Data in column 1 were taken from this study and in column 2 from Iversen et al. (2008).

\begin{tabular}{|c|c|c|}
\hline \multirow[t]{2}{*}{ Strain } & \multicolumn{2}{|c|}{ Hybridization (mean \pm SD; \%) with labelled DNA from: } \\
\hline & C. condimenti $1330^{\mathrm{T}}$ & C. universalis NCTC $9529^{\mathrm{T}}$ \\
\hline C. sakazakii ATCC $29544^{\mathrm{T}}$ & $40.3 \pm 7.7$ & $55.5 \pm 1.0$ \\
\hline C. malonaticus CDC $1058-77^{\mathrm{T}}$ & $53.0 \pm 14.4$ & $60.1 \pm 1.3$ \\
\hline C. muytjensii ATCC $51329^{\mathrm{T}}$ & $42.0 \pm 9.3$ & $53.1 \pm 6.6$ \\
\hline C. dublinensis LMG $23823^{\mathrm{T}}$ & $54.2 \pm 8.7$ & $45.9 \pm 2.0$ \\
\hline C. turicensis LMG $23827^{\mathrm{T}}$ & $47.9 \pm 5.9$ & $55.0 \pm 3.3$ \\
\hline C. universalis NCTC $9529^{\mathrm{T}}$ & $50.7 \pm 7.6$ & - \\
\hline
\end{tabular}


The species description is based on four strains. Cells are straight, Gram-negative, non-spore-forming rods with variable motility (the type strain is non-motile). Colonies on TSA incubated at $37{ }^{\circ} \mathrm{C}$ for $24 \mathrm{~h}$ are $2-3 \mathrm{~mm}$ in diameter, opaque, circular and yellow. Grows on MacConkey agar. In TSB, grows at $45^{\circ} \mathrm{C}$ (optimum $37{ }^{\circ} \mathrm{C}$ ), but not at $5{ }^{\circ} \mathrm{C}$. No haemolysis is observed on sheep blood agar at $37^{\circ} \mathrm{C}$. Produces catalase, $\alpha$-glucosidase, $\beta$-galactosidase and DNase, but not oxidase. Produces acetoin (Voges-Proskauer positive), but not indole from tryptophan or hydrogen sulphide. Does not hydrolyse gelatin or urea. Reduces nitrate. Utilizes malonate, ornithine and citrate. Produces acid from glucose, 10-methyl $\alpha$-D-glucopyranoside, dulcitol, inositol, melezitose, lactulose, sucrose, L-arabinose, cellobiose, lactose, myo-inositol, L-rhamnose, D-mannitol, $\mathrm{N}$-acetylglucosamine, salicin, maltitol, D-fucose, amygdalin and galacturonic acid, but not from turanose, D-sorbitol, putrescine, trans-aconitate, L-fucose, adonitol, 5-ketogluconate or 4-aminobutyrate. Variable results are obtained for acid production from cisaconitate and palatinose and production of gas from glucose (the type strain is negative). Resistant to doxycycline; susceptible to the other antimicrobials tested. The API $20 \mathrm{E}$ and ID 32 E profiles of the type strain are 3205373 and 24276777051 , respectively.

The type strain is NCTC $9529^{\mathrm{T}}\left(=\mathrm{CECT} 7864^{\mathrm{T}}=\mathrm{LMG}\right.$ $26249^{\mathrm{T}}$ ), isolated from fresh water and deposited at the NCTC (London) in 1954.

\section{Acknowledgements}

We are grateful to Nottingham Trent University for their financial support. We are also grateful to Dr Roxana Beaz-Hidalgo for her assistance with the DNA-DNA hybridization and also thank Jean Euzéby for helping to correct the species name. The development of the Cronobacter MLST website (http://pubmlst.org/cronobacter; Jolley et al., 2004) was funded by the Wellcome Trust.

\section{References}

Baldwin, A., Loughlin, M., Caubilla-Barron, J., Kucerova, E., Manning, G., Dowson, C. \& Forsythe, S. (2009). Multilocus sequence typing of Cronobacter sakazakii and Cronobacter malonaticus reveals stable clonal structures with clinical significance which do not correlate with biotypes. BMC Microbiol 9, 223.

British Society for Antimicrobial Chemotherapy (2010). BSAC methods for antimicrobial susceptibility testing, version 9. http:// www.bsac.org.uk/Resources/BSAC/Version_9.1_March_2010_final. pdf.

Caubilla-Barron, J., Hurrell, E., Townsend, S., Cheetham, P., LocCarrillo, C., Fayet, O., Prère, M.-F. \& Forsythe, S. J. (2007). Genotypic and phenotypic analysis of Enterobacter sakazakii strains from an outbreak resulting in fatalities in a neonatal intensive care unit in France. J Clin Microbiol 45, 3979-3985.

Chun, J., Lee, J.-H., Jung, Y., Kim, M., Kim, S., Kim, B. K. \& Lim, Y.-W. (2007). EzTaxon: a web-based tool for the identification of prokaryotes based on $16 \mathrm{~S}$ ribosomal RNA gene sequences. Int J Syst Evol Microbiol 57, 2259-2261.

Duaga, C. \& Breuwer, P. (2008). Taxonomy and physiology of Enterobacter sakazakii. In Enterobacter sakazakii, pp. 1-26. Edited by
J. M. Farber \& S. J. Forsythe. Washington, DC: American Society for Microbiology.

Farmer, J. J., III, Asbury, M. A., Hickman, F. W., Brenner, D. J. \& Enterobacteriaceae study group (1980). Enterobacter sakazakii: a new species of 'Enterobacteriaceae' isolated from clinical specimens. Int J Syst Bacteriol 30, 569-584.

Forsythe, S. J. (2005). Enterobacter sakazakii and other bacteria in powdered infant milk formula. Matern Child Nutr 1, 44-50.

Harayama, S. \& Kasai, H. (2006). Bacterial phylogeny reconstruction from molecular sequences. In Molecular Identification, Systematics, and Population Structure of Prokaryotes, pp. 105-140. Edited by E. Stackebrandt. Berlin, Heidelberg: Springer-Verlag.

Ibarz Pavón, A. B. \& Maiden, M. C. (2009). Multilocus sequence typing. Methods Mol Biol 551, 129-140.

Iversen, C. \& Forsythe, S. J. (2004). Isolation of Enterobacter sakazakii and other Enterobacteriaceae from powdered infant formula milk and related products. Food Microbiol 21, 771-777.

Iversen, C., Waddington, M., On, S. L. W. \& Forsythe, S. (2004). Identification and phylogeny of Enterobacter sakazakii relative to Enterobacter and Citrobacter species. J Clin Microbiol 42, 5368-5370.

Iversen, C., Lancashire, L., Waddington, M., Forsythe, S. \& Ball, G. (2006a). Identification of Enterobacter sakazakii from closely related species: the use of artificial neural networks in the analysis of biochemical and 16S rDNA data. BMC Microbiol 6, 28.

Iversen, C., Waddington, M., Farmer, J. J., III \& Forsythe, S. J. (2006b). The biochemical differentiation of Enterobacter sakazakii genotypes. BMC Microbiol 6, 94.

Iversen, C., Lehner, A., Mullane, N., Bidlas, E., Cleenwerck, I., Marugg, J., Fanning, S., Stephan, R. \& Joosten, H. (2007). The taxonomy of Enterobacter sakazakii: proposal of a new genus Cronobacter gen. nov. and descriptions of Cronobacter sakazakii comb. nov. Cronobacter sakazakii subsp. sakazakii, comb. nov., Cronobacter sakazakii subsp. malonaticus subsp. nov., Cronobacter turicensis sp. nov., Cronobacter muytjensii sp. nov., Cronobacter dublinensis sp. nov. and Cronobacter genomospecies 1. BMC Evol Biol 7, 64.

Iversen, C., Mullane, N., McCardell, B., Tall, B. D., Lehner, A., Fanning, S., Stephan, R. \& Joosten, H. (2008). Cronobacter gen. nov., a new genus to accommodate the biogroups of Enterobacter sakazakii, and proposal of Cronobacter sakazakii gen. nov., comb. nov., Cronobacter malonaticus sp. nov., Cronobacter turicensis sp. nov., Cronobacter muytjensii sp. nov., Cronobacter dublinensis sp. nov., Cronobacter genomospecies 1, and of three subspecies, Cronobacter dublinensis subsp. dublinensis subsp. nov., Cronobacter dublinensis subsp. lausannensis subsp. nov. and Cronobacter dublinensis subsp. lactaridi subsp. nov. Int J Syst Evol Microbiol 58, 1442-1447.

Jolley, K. A., Chan, M.-S. \& Maiden, M. C. J. (2004). mlstdbNet distributed multi-locus sequence typing (MLST) databases. $B M C$ Bioinformatics 5, 86.

Joseph, S. \& Forsythe, S. J. (2011). Predominance of Cronobacter sakazakii sequence type 4 in neonatal infections. Emerg Infect Dis 17, 1713-1715.

Kimura, M. (1980). A simple method for estimating evolutionary rates of base substitutions through comparative studies of nucleotide sequences. J Mol Evol 16, 111-120.

Kucerova, E., Clifton, S. W., Xia, X.-O., Long, F., Porwollik, S., Fulton, L., Fronick, C., Minx, P., Kyung, K. \& other authors (2010). Genome sequence of Cronobacter sakazakii BAA-894 and comparative genomic hybridization analysis with other Cronobacter species. PLoS One 5, e9556.

Kucerova, E., Joseph, S. \& Forsythe, S. (2011). The Cronobacter genus: ubiquity and diversity. Quality Assurance and Safety of Crops and Foods 3, 104-122. 
Lacher, D. W., Steinsland, H., Blank, T. E., Donnenberg, M. S. \& Whittam, T. S. (2007). Molecular evolution of typical enteropathogenic Escherichia coli: clonal analysis by multilocus sequence typing and virulence gene allelic profiling. J Bacteriol 189, 342-350.

Larkin, M. A., Blackshields, G., Brown, N. P., Chenna, R., McGettigan, P. A., McWilliam, H., Valentin, F., Wallace, I. M., Wilm, A. \& other authors (2007). CLUSTAL W and CLUSTAL X version 2.0. Bioinformatics 23, 2947-2948.

Marmur, J. (1961). A procedure for the isolation of deoxyribonucleic acid from microorganisms. J Mol Biol 3, 208-218.

Osaili, T. \& Forsythe, S. (2009). Desiccation resistance and persistence of Cronobacter species in infant formula. Int J Food Microbiol 136, 214-220.

Rosselló-Mora, R. (2006). DNA-DNA reassociation methods applied to microbial taxonomy and their critical evaluation. In Molecular Identification, Systematics, and Population Structure of Prokaryotes, pp. 23-50. Edited by E. Stackebrandt. Berlin: Springer.

Saitou, N. \& Nei, M. (1987). The neighbor-joining method: a new method for reconstructing phylogenetic trees. Mol Biol Evol 4, 406425.

Stackebrandt, E. \& Goebel, B. M. (1994). Taxonomic note: a place for DNA-DNA reassociation and $16 \mathrm{~S}$ rRNA sequence analysis in the present species definition in bacteriology. Int J Syst Bacteriol 44, 846849.
Tamura, K., Dudley, J., Nei, M. \& Kumar, S. (2007). MEGA4: molecular evolutionary genetics analysis (MEGA) software version 4.0. Mol Biol Evol 24, 1596-1599.

Townsend, S. M., Hurrell, E., Caubilla-Barron, J., Loc-Carrillo, C. \& Forsythe, S. J. (2008). Characterization of an extended spectrum betalactamase Enterobacter hormaechei nosocomial outbreak, and other Enterobacter hormaechei misidentified as Cronobacter (Enterobacter) sakazakii. Microbiology 154, 3659-3667.

Turcovský, I., Kuniková, K., Drahovská, H. \& Kaclíková, E. (2011). Biochemical and molecular characterization of Cronobacter spp. (formerly Enterobacter sakazakii) isolated from foods. Antonie van Leeuwenhoek 99, 257-269.

Urdiain, M., López-López, A., Gonzalo, C., Busse, H. J., Langer, S., Kämpfer, P. \& Rosselló-Móra, R. (2008). Reclassification of Rhodobium marinum and Rhodobium pfennigii as Afifella marina gen. nov. comb. nov. and Afifella pfennigii comb. nov., a new genus of photoheterotrophic Alphaproteobacteria and emended descriptions of Rhodobium, Rhodobium orientis and Rhodobium gokarnense. Syst Appl Microbiol 31, 339-351.

Wayne, L. G., Brenner, D. J., Colwell, R. R., Grimont, P. A. D., Kandler, O., Krichevsky, M. I., Moore, L. H., Moore, W. E. C., Murray, R. G. E. \& other authors (1987). International Committee on Systematic Bacteriology. Report of the ad hoc committee on reconciliation of approaches to bacterial systematics. Int J Syst Bacteriol 37, 463-464. 